\title{
In vitro comparative assessment of the inhibitory effects of single and combined spices against glucose-synthesizing enzymes
}

\author{
Temitayo Esther Adeyeoluwa, Fatai Oladunni Balogun, Anofi Omotayo Tom \\ Ashafa* \\ Phytomedicine and Phytopharmacology Research Group, Department of Plant Sciences, University of the Free State, QwaQwa \\ Campus, Private Bag x13, Phuthaditjhaba 9866, QwaQwa, Free State, South Africa
}

*For correspondence: Email: ashafaaot@ufs.ac.za

Sent for review: 15 November 2019

Revised accepted: 23 May 2020

\begin{abstract}
Purpose: To assess the individual and synergistic inhibitory activities of five (5) tropical spices, viz, Zingiber officinale Rosc., Xylopia aethiopica (Dun.) A. Rich, Piper guineense Schum \& Thonn, Myristica fragrans Houtt. and Allium sativum L. against glucose hydrolysing enzymes.

Methods: In vitro assessment of the alpha-amylase and alpha-glucosidase inhibitory activities of cold water, hot water, ethanol and aqueous-ethanol extracts of each of the five spices and their combination was investigated using enzymatic protocols. Acarbose was used as the standard.

Results: Only four extracts showed strong inhibition against alpha-glucosidase and weak inhibition against alpha-amylase. Going by their half-maximal inhibitory concentrations (IC50), the combined spices exhibited the best concurrent inhibitory activity against both hydrolysing enzymes (665.83 \pm $27.50 \mu \mathrm{g} / \mathrm{mL}$ for alpha-glucosidase) and (1166.86 $\pm 14.70 \mu \mathrm{g} / \mathrm{mL}$ for alpha-amylase).

Conclusion: The findings from this study demonstrate the enhanced antihyperglycemic potentials of the combined spices compared to the individual spices for the management of diabetes.
\end{abstract}

Keywords: Hyperglycemia, Diabetes, Alpha-amylase, Alpha-glucosidase, Zingiber officinale, Xylopia aethiopica, Piper guineense, Myristica fragrans, Allium sativum, Spices

\begin{abstract}
This is an Open Access article that uses a fund-ing model which does not charge readers or their institutions for access and distributed under the terms of the Creative Commons Attribution License (http://creativecommons.org/licenses/by/4.0) and the Budapest Open Access Initiative (http://www.budapestopenaccessinitiative.org/read), which permit unrestricted use, distribution, and reproduction in any medium, provided the original work is properly credited.

Tropical Journal of Pharmaceutical Research is indexed by Science Citation Index (SciSearch), Scopus, International Pharmaceutical Abstract, Chemical Abstracts, Embase, Index Copernicus, EBSCO, African Index Medicus, JournalSeek, Journal Citation Reports/Science Edition, Directory of Open Access Journals (DOAJ), African Journal Online, Bioline International, Open-J-Gate and Pharmacy Abstracts
\end{abstract}

\section{INTRODUCTION}

Diabetes continues to mount danger globally as a result of an increase in the intake of refined food and an unhealthy dietary lifestyle. Type-2 diabetes, also known as insulin-resistant diabetes, accounts for more than $90 \%$ of diabetes cases worldwide [1]. As stated by the International Diabetes Federation [2], over 1.8 million people are living with type-2 diabetes in South Africa and there are over 425 million cases worldwide. Undoubtedly, these figures are expected to significantly increase by the year 2045 particularly amongst the low and average income earners, while more than $50 \%$ cases of diabetes mellitus go undiagnosed globally [3]. 
Adverse effects from conventionally used antidiabetic drugs such as sulfonylurea, incretin, and thiazolidinedione inhibitors [4] continue to create pressure for the discovery of natural substances. These natural products have become popular remedial and health-enhancing agents because of their known possession of secondary metabolites [5]. Health benefits derived from spices are due to these secondary metabolites such as phenolic compounds which have been reported to be potent antihyperglycemic and anti-diabetic agents [6].

Ginger has been reported to be effective and safe in the management of hyperglycemia, obesity, inflammation and oxidative stress [4]. Additionally, a potential glucose-lowering effect of Ethiopian pepper on acute hyperlipidemic rats while inhibiting the exponential weight gain of the animals has been reported [7]. Piperine, the principal alkaloid in black pepper was been reported to be an effective anti-hyperglycemic agent at sub-acute doses [8]. Nutmeg has been used traditionally in the management of diabetes in India and other countries [9] while information on the antioxidative and anti-inflammatory actions of garlic in addition to its traditional use in controlling or managing diabetes over several generations have been reported [10].

The scientific basis for the combination of these spices in traditional formulations as well as a comparative evaluation of the combination of the five spices to each spice was investigated in this study.

\section{EXPERIMENTAL}

\section{Chemicals}

Acarbose, sodium phosphate buffer, potassium phosphate buffer, porcine pancreatic alphaamylase, starch, 3,5 dinitrosalicylic acid (DNS), alpha-glucosidase from Saccharomyces cerevisiae, p-nitrophenylglucopyranoside (p$\mathrm{NPG})$, sodium carbonate $\left(\mathrm{Na}_{2} \mathrm{CO}_{3}\right)$, and solvents were obtained from Sigma-Aldrich (South Africa).

\section{Plant materials}

Ginger (Zingiber officinale Rosc.), Ethiopian pepper (Xylopia aethiopica (Dun.) A. Rich, black pepper (Piper guineense Schumach. \& Thonn), nutmeg (Myristica fragrans Houtt.) and garlic (Allium sativum L.) were purchased in August 2018 from local herb sellers at Ibadan, Nigeria. The spices were identified and authenticated by Prof AOT Ashafa of the Department of Plant Sciences, University of the Free state (UFS). Voucher specimens of the spices deposited at the University of the Free State QwaQwa Campus herbarium were AdeMed/01/2018/QHB (Ginger), AdeMed/02/2018/QHB (Ethiopian pepper), AdeMed/03/2018/QHB (Black pepper), AdeMed/04/2018/QHB (Nutmeg), AdeMed/05/ 2018/QHB (Garlic). The spices were separately dried, ground and stored in sealed glass bottles at $4^{\circ} \mathrm{C}$ until they were to be used.

\section{Extraction procedure}

Five grams of each powdered spice were extracted separately with $250 \mathrm{~mL}$ each of cold water, hot water (boiled at $90^{\circ} \mathrm{C}$ ), ethanol and aqueous-ethanol for 2 days and filtered using Whatman No. 1 filter paper. Filtrates from the ethanol extraction were concentrated under a stream of cold air while those from the water and aqueous-ethanol extractions were evaporated at $60^{\circ} \mathrm{C}$ with the use of a hot water bath. An appropriate quantity of each dried extract was redissolved in distilled water (water extracts) or dimethyl sulfoxide (DMSO) (ethanol and aqueous-ethanol extracts) to attain a stock solution of $1 \mathrm{~g} / \mathrm{L}$.

\section{Evaluation of hypoglycemic activity}

\section{Alpha-amylase inhibitory assay}

Fifty microliters of extract or acarbose (control) at concentrations of $1.000,0.750,0.500,0.250$ and $0.125 \mathrm{~g} / \mathrm{L}$ was added to buffer (sodium phosphate, 0.02M SPB), ( $\mathrm{pH} 6.9)$, into which $\alpha-$ amylase $(0.5 \mathrm{~g} / \mathrm{L})$ had been included, and incubated for $10 \mathrm{~min}$ at $25^{\circ} \mathrm{C}$. Afterwards, $50 \mu \mathrm{L}$ of starch (one per cent) in SPB solution was introduced into each tube and the mixture reincubated at $25^{\circ} \mathrm{C}$ for $10 \mathrm{~min}$. The reaction process was terminated with $100 \mu \mathrm{L}$ DNS colour reagent. The tubes were further suspended in $100^{\circ} \mathrm{C}$ water bath for $10 \mathrm{~min}$, cooled and the strength lessened with distilled water $(15 \mathrm{~mL})$. The absorbance was read at $540 \mathrm{~nm}$ with a WPA Biowave II spectrophotometer (Biochrom, Cambridge, UK) [11].

The extracts' inhibiting potential $(\mathrm{H})$ evaluated adopting Eq 1.

$H(\%)=\{(A c-A e) / A c\} \times 100$

where Ac and Ae represent the absorbance values of control (water or DMSO) and extract, respectively.

\section{Alpha-glucosidase inhibitory assay}

In labelled test tubes, $50 \mu \mathrm{L}$ of varied concentrations $(0.125-1.000 \mathrm{~g} / \mathrm{L})$ of the extracts 
or control (acarbose) was combined with $100 \mu \mathrm{L}$ of $0.02 \mathrm{M}$ phosphate buffer (PB) ( $\mathrm{pH}$ 6.9) into which $1.0 \mathrm{U} / \mathrm{mL}$ of the $\alpha$-glucosidase solution had been included. Fifty microliters of $5 \mathrm{mM}$ p-NPG solution in $0.02 \mathrm{M} \mathrm{PB}(\mathrm{pH} 6.9)$ was added and incubated for $30 \mathrm{~min}$ at $37^{\circ} \mathrm{C}$. The reaction was stopped with $2 \mathrm{~mL}$ of $0.1 \mathrm{M}$ sodium carbonate and its absorbance read at $405 \mathrm{~nm}$ using a WPA Biowave II spectrophotometer [11].

The extracts' inhibitory potential $(\mathrm{H})$ was determined using Eq 1 above.

Half maximal concentration $\left(\mathrm{IC}_{50}\right)$ was obtained from the linear equation as in Eq 2.

$y=m x+c$

where (value is 50) is the percent activity, $m$ is the slope, $c$ is the intercept and $x$ is the calculated $\mathrm{IC}_{50}$.

\section{Statistical analysis}

The statistical evaluation of the results was achieved by analyzing the data using two-way analyses of variance with the Bonferroni posttest. Three autonomous samples were obtained and their results expressed as mean \pm standard deviation (SD) using GraphPad Prism Software, version 5.01 for Windows, San Diego, California, USA.

\section{RESULTS}

The Aq.ethanol extract of nutmeg (IC $50: 270.75 \pm$ $9.40 \mu \mathrm{g} / \mathrm{mL}$ ) and the cold water extract of garlic (IC $50: 351.88 \pm 11.10 \mu \mathrm{g} / \mathrm{mL})$ depicted $(p<0.05)$ higher $\alpha$-amylase inhibitory activity when compared with the other samples. There was an insignificant statistical distinction $(p>0.05)$ between acarbose $\left(\mathrm{IC}_{50}: 487.47 \pm 12.40 \mu \mathrm{g} / \mathrm{mL}\right)$ and the Aq.ethanol extracts of Ethiopian pepper, black pepper, garlic and mixed spices(Table 1).

Aqueous ethanol extract of garlic $\left(\mathrm{IC}_{50}\right.$ : $364.71 \pm 21.40 \mu \mathrm{g} / \mathrm{mL})$ and nutmeg $\left(\mathrm{IC}_{50}: 428.28\right.$ $\pm 31.60 \mu \mathrm{g} / \mathrm{mL}$ ) showed the best inhibitory activities against alpha-glucosidase while acarbose $\left(\mathrm{IC}_{50}=1157.32 \pm 38.30 \mu \mathrm{g} / \mathrm{mL}\right)$ revealed an increased $(p<0.05) \quad \mathrm{IC}_{50}$ activity against $\alpha$-glucosidase than all the extracts of the mixed spices (Table 2).

Extracts with significantly milder inhibition against $\alpha$-amylase and stronger inhibition against $\alpha$ glucosidase were ethanol and hot water extracts of Ethiopian pepper, ethanol extract of nutmeg, and ethanol extract of the mixed spices.

Table 1: Half-inhibitory concentration ( $\left.\mathrm{IC}_{50}\right)$ values for in vitro inhibitory activity of extracts of five tropical spices and their combination against $\alpha$-amylase

\begin{tabular}{lcccc}
\hline Parameter & \multicolumn{4}{c}{$\mathbf{I C}_{50} \mathbf{\mu g} / \mathbf{m L}$} \\
\cline { 2 - 5 } & $\begin{array}{c}\text { Cold water } \\
\text { extract }\end{array}$ & $\begin{array}{c}\text { Hot water } \\
\text { extract }\end{array}$ & Ethanol extract & $\begin{array}{c}\text { Aq. } \text { ethanol } \\
\text { extract }\end{array}$ \\
\hline Ginger & $1402.13 \pm 13.10^{\mathrm{a}}$ & $1354.66 \pm 13.20^{\mathrm{a}}$ & $639.48 \pm 19.10^{\mathrm{d}}$ & $694.72 \pm 84.90^{\mathrm{d}}$ \\
Ethiopian pepper & $1310.03 \pm 12.00^{\mathrm{g}}$ & $3640.07 \pm 52.90^{\mathrm{h}}$ & $1433.23 \pm 10.60^{\mathrm{f}}$ & $581.77 \pm 57.90^{\mathrm{e}}$ \\
Blackpepper & $1486.69 \pm 12.40^{\mathrm{i}}$ & $749.13 \pm 42.20^{\mathrm{c}}$ & $726.77 \pm 12.60^{\mathrm{c}}$ & $603.28 \pm 19.10^{\mathrm{e}}$ \\
Nutmeg & $727.21 \pm 7.10^{\mathrm{c}}$ & $1635.14 \pm 88.20^{\mathrm{j}}$ & $1436.74 \pm 57.70^{\mathrm{f}}$ & $270.75 \pm 9.40^{\mathrm{k}}$ \\
Garlic & $351.88 \pm 11.10^{\mathrm{l}}$ & $922.84 \pm 69.50^{\mathrm{m}}$ & $767.2 \pm 53.10^{\mathrm{c}}$ & $478.08 \pm 61.70^{\mathrm{e}}$ \\
Mixed spices & $1153.89 \pm 11.00^{\mathrm{b}}$ & $1038.39 \pm 11.20^{\mathrm{n}}$ & $1166.86 \pm 14.70^{\mathrm{b}}$ & $545.34 \pm 87.20^{\mathrm{e}}$ \\
Acarbose & $487.47 \pm 12.40^{\mathrm{e}}$ & & & \\
\hline ta are mean $\pm \mathrm{SD}(\mathrm{n}=3)$. Varying superscripts on the values indicated a significant $(p<0.05)$ from each other
\end{tabular}

Table 2: Half-inhibitory concentration ( $\mathrm{IC}_{50}$ ) values for in vitro inhibitory activity of extracts of five tropical spices and their combination against $\alpha$-glucosidase

\begin{tabular}{lcccc}
\hline Parameter & \multicolumn{4}{c}{$\mathbf{I C}_{50} \mathbf{\mu g} / \mathbf{m L}$} \\
\cline { 2 - 5 } & $\begin{array}{c}\text { Cold water } \\
\text { extract }\end{array}$ & $\begin{array}{c}\text { Hot water } \\
\text { extract }\end{array}$ & Ethanol extract & $\begin{array}{c}\text { Aq. ethanol } \\
\text { extract }\end{array}$ \\
\hline Ginger & $1581.75 \pm 36.50^{\mathrm{a}}$ & $1441.34 \pm 60.0^{\mathrm{c}}$ & $1129.72 \pm 47.80^{\mathrm{e}}$ & $804.53 \pm 53.70^{\mathrm{g}}$ \\
Ethiopian pepper & $1243.67 \pm 42.60^{\mathrm{b}}$ & $981.54 \pm 22.90^{\mathrm{d}}$ & $892.44 \pm 37.60^{\mathrm{f}}$ & $559.94 \pm 44.90^{\mathrm{h}}$ \\
Black pepper & $1355.01 \pm 60.70^{\mathrm{i}}$ & $796.82 \pm 49.70^{\mathrm{j}}$ & $647.12 \pm 47.90^{\mathrm{k}}$ & $647.55 \pm 23.60^{\mathrm{k}}$ \\
Nutmeg & $1218.34 \pm 25.90^{\mathrm{b}}$ & $1208.62 \pm 34.90^{\mathrm{b}}$ & $641.36 \pm 40.00^{\mathrm{k}}$ & $428.28 \pm 31.60^{\mathrm{a}}$ \\
Garlic & $1004.81 \pm 52.50^{\mathrm{f}}$ & $1267.41 \pm 14.80^{\mathrm{b}}$ & $939.64 \pm 68.70^{\mathrm{f}}$ & $364.71 \pm 21.40^{\mathrm{1}}$ \\
Mixed spices & $978.98 \pm 28.90^{\mathrm{f}}$ & $1145.83 \pm 26.70^{\mathrm{b}}$ & $665.83 \pm 26.50^{\mathrm{k}}$ & $700.10 \pm 46.80^{\mathrm{k}}$ \\
Acarbose & $1157.32 \pm 38.30^{\mathrm{eb}}$ & & & \\
\hline
\end{tabular}

Values represented as mean $\pm S D(n=3)$. Varying superscripts on the values indicate significant difference from each other $(p<0.05)$ 


\section{DISCUSSION}

An unhealthy dietary lifestyle has been incriminated in the development and prevalence of diabetes mellitus (DM) [4]. Alteration in diet composition and lifestyle is therefore vital in its prevention and management. The use of spices in diet is being acknowledged as a means of managing DM since diets rich in spices have been found to be abundant in medicinal compounds [12].

Synthetic antidiabetic drugs that are conventionally utilised in the management of diabetes are replete with various side effects such as weight gain, decreased gastric emptying leading to gastrointestinal discomfort, nausea, infections and headaches [13]. For instance, acarbose, a synthetic alpha-glucosidase inhibitor, is known to cause flatulence, diarrhoea, and abdominal discomfort [14]. Medicinal plants are thus expected to inhibit enzymes liable for the breakdown of ingested carbohydrates and sugars in the intestines without the accompanying adverse effects associated with synthetic drugs.

The inhibitory effect of the combination of five tropical spices when compared to their individual effects against alpha-amylase and alphaglucosidase was evaluated in this study. All the spices exhibited some considerable inhibition of either or both enzymes. These spices are amply endowed with varying but significant amounts of antidiabetic compounds like allium in garlic [15] and gingerol in ginger [4]. The synergistic effect of combined spices has been reported to increase their hypoglycemic potential [16] and when hyperglycemia is well controlled, both oxidative stress and diabetes are better managed [10]. In fact, black pepper is more effective in combination with other established anti-diabetic herbs or spices than black pepper alone in diabetes management [17]. Furthermore, combined spices have been found to possess minimal unpleasant effects (if any), because they are utilised at reduced quantities [18]. For instance, the strong odour that accompanies the use of garlic supplements may hardly be perceived in combined formulations.

The possibility that combined spices may be synergistic in effect may be due to their mechanism of action. For example, ginger increases the uptake of glucose by body cells in an insulin-independent way (4), Ethiopian pepper activates the beta cells of the pancreas [7] and nutmeg repairs damaged beta cells of the pancreas [19]. Each spice would have a separate effect that would culminate in the observed antidiabetic outcome.

Effective antidiabetic agents have been validated to be mild $\alpha$-amylase and strong a-glucosidase in-activators [20]. Based on study results, the ethanol and hot water extracts of Ethiopian pepper, the ethanol extracts of nutmeg and the mixed spices demonstrated much stronger inhibitory effects against $\alpha$-glucosidase than $\alpha$ amylase.

It is worthy of note that although the mixed spices did not exhibit the strongest inhibitory activity against either of the hydrolysing enzymes, its ethanol extract exhibited the best concurrent mild inhibition against $\alpha$-amylase and strong inhibition against a-glucosidase. The other extracts (ethanol and hot water extracts of Ethiopian pepper, and ethanol extract of nutmeg) exhibited less concurrent activity than the mixed spices, based on their $\mathrm{IC}_{50}$ values. Interestingly, in a study carried out by Kumar and Srivastava [9], nutmeg was mentioned as one of the essential anti-diabetic spices used in North Indian kitchens, indicating its significant antidiabetic use in tradition [9].

The Aq.ethanol extracts of all the spices and their mixture exhibited the highest level of inhibition of both carbohydrate-hydrolysing enzymes, in contrast to their aqueous extracts. Ethanol is said to be more efficient in extracting polyphenols and polar solvents are potent for the recovery of polyphenols from plants [21]. Organic solvents have also been shown to be better extractants of antioxidants from spices than water [22]. This suggests a preference in the use of ethanol and other organic solvents for the extraction of potent medicinal molecules.

Indeed, Morakinyo et al [23] established the antihyperglycemic activity of ginger ethanol extract in streptozotocin-induced diabetic rats more significantly than its water extract after 7 days of treatment. The ethanol extract of Ethiopian pepper fruits was also shown to significantly reduce triglycerides, total cholesterol, and postprandial glycemia in insulin resistant rats [7]. Ethanol extract of black pepper to a larger extent lowered the levels of glucose in rats induced with alloxan [24] while Pashapoor et al [19] reported the dose-dependent regenerative effect of the petroleum ether extract of nutmeg on damaged pancreatic beta cells in diabetic Wistar rats. Furthermore, the ethanol extract of garlic reduced blood glucose in albino rats [25].

By all indications, therefore, the potency of the ethanol-based extracts of the mixed spices compared to its water-based extracts is 
justifiable. Considering its traditional use in some cultures, it can be recommended that ethanolbased solvents are preferably employed in order to derive optimal anti-diabetic benefits from this spice mixture.

\section{CONCLUSION}

Based on the results of this study, a mixture of all five spices is recommended as a potent antidiabetic food additive, when compared to each of the single spices. No known previous report of the hypoglycemic effect of the combination of these spices as used traditionally has been documented, to the best of our knowledge. Thus, the regular or daily use of the combination of these five spices in diet may be encouraged as this might afford a prophylactic and/or therapeutic benefit to diabetic patients.

\section{DECLARATIONS}

\section{Acknowledgement}

The authors appreciate the assistance received from the DRD of the University of the Free State, QwaQwa Campus, South Africa for financing the study (no. 211427604). We also thank the postgraduate school for a doctoral tuition bursary waiver to Adeyeoluwa TE (no. 2017165248).

\section{Conflict of interest}

No conflict of interest is associated with this study.

\section{Contribution of authors}

We declare that this work was done by the authors named in this article and all liabilities on claims related to the content of this article will be borne by them. AOTA conceived and designed the study, TEA collected and analysed the data as well as wrote the manuscript, while FOB supervised the project and edited the manuscript. All authors read and approved the manuscript for publication.

\section{Open Access}

This is an Open Access article that uses a funding model which does not charge readers or their institutions for access and distributed under the terms of the Creative Commons Attribution License (http://creativecommons.org/licenses/by/ 4.0) and the Budapest Open Access Initiative (http://www.budapestopenaccessinitiative.org/rea d), which permit unrestricted use, distribution, and reproduction in any medium, provided the original work is properly credited.

\section{REFERENCES}

1. Hall V, Thomsen RW, Henriksen O, Lohse N. Diabetes in sub Saharan Africa 1999-2011: Epidemiology and public health implications. A systematic review. BMC Public Health 2011; 11: 564.

2. IDF. International Diabetes Federation, 2017. https://www.idf.org/our-network/regions-

members/africa/members/25-south-africa. Accessed 29 April 2019.

3. Pheiffer C, Wyk VP, Joubert JD, Levitt N, Nglazi MD, Bradshaw D. The prevalence of type 2 diabetes in South Africa: A systematic review protocol. BMJ Open 2018; 8(7): 21-29.

4. Daily JW, Yang M, Kim DS, Park S. Efficacy of ginger for treating Type 2 diabetes: A systematic review and metaanalysis of randomized clinical trials. J. Ethn. Foods 2015; 2(1): 36-43.

5. Tungmunnithum $D$, Thongboonyou $A$, Pholboon $A$ and Yangsabai A. Flavonoids and other phenolic compounds from medicinal plants for pharmaceutical and medical aspects: An overview. Medicines 2018; 5(3): 93.

6. Ge Q, Chen L, Chen K. Treatment of Diabetes Mellitus Using iPS Cells and Spice Polyphenols. J. Diabetes Res 2017: 1-11 Article ID 5837804.

7. Etoundi OCB, Kuate D, Ngondi JL, Oben EJ. Effects of extracts of Hypodaphnis zenkeri and Xylopia aethiopica on blood lipids, glycemia and body weight of triton WR1339 and insulin- resistant rats. Int. J. Res. Ayurveda Pharm 2013; 4(5): 736-741.

8. Atal S, Agrawal RP, Vyas $S$, Phadnis $P$, Rai $N$. Evaluation of the effect of piperine per se on blood glucose level in alloxan-induced diabetic mice. Acta Pol Pharm ñ Drug Research 2012; 69(5): 965-969.

9. Kumar S, Srivastava MK. Anti-diabetic properties of common spices found in north Indian kitchens. Indian J. Sci. Res 2018; 08(2): 117-120.

10. Liu CT, Hsu TW, Chen KM, Tan YP, Lii CK, Sheen LY. The antidiabetic effect of garlic oil is associated with ameliorated oxidative stress but not ameliorated level of pro-inflammatory cytokines in skeletal muscle of streptozotocin-induced diabetic rats. J Tradit Complement Med 2012; 2(2): 135-44.

11. McCue $P$, Shetty $K$. Inhibitory effects of rosmarinic acid extracts on porcine pancreatic amylase in-vitro. Asian Pac J Clin Nutr 2004; 13(1): 101-106.

12. Sattar NA, Hussain F, Iqbal T, Sheikh MA. Determination of in vitro antidiabetic effects of Zingiber officinale Roscoe. Braz. J. Pharm. Sci 2012; 48(4): 601-607.

13. Chaudhury A, Duvoor C, Dendi VSR, Kraleti S, Chada A, Ravilla R, Marco A, Shekhawat NS, Montales MT, Kuriakose K, Sasapu A, Beebe A, Patil N, Musham CK, Lohani GP, Mirza W. Clinical review of antidiabetic drugs: Implications for type 2 diabetes mellitus 
management. Front Endocrinol (Lausanne) 2017; 8:112.

14. Bösenberg $L H$, van Zyl DG. The mechanism of action of oral antidiabetic drugs: $A$ review of recent literature. JEMDSA 2008; 13(3): 80-88.

15. Padiya R, Banerjee SK. Garlic as an anti-diabetic agent: Recent progress and patent reviews. Recent Pat Food NutrAgric 2013; 5: 105-127.

16. Panda A, Jena S, Sahu PK, Nayak S, Padhi P. Effect of polyherbal mixtures on the treatment of diabetes. ISRN Endocrinol 2013: 1-5.

17. Sarfraz M, Khaliq T, Khan JA, Aslam B. Effect of aqueous extract of black pepper and ajwa seed on liver enzymes in alloxan-induced diabetic Wister albino rats. Saudi Pharm J 2017; 25(4): 449-452.

18. Otunola GA, Afolayan AJ. Antidiabetic effect of combined spices of Allium sativum, Zingiber officinale and Capsicum frutescens in alloxan-induced diabetic rats. Front Life Sci 2015; 8(4): 314-323.

19. Pashapoor A, Mashhadyrafie $S$, Mortazavi $P$. Ameliorative effect of Myristica fragrans (nutmeg) extract on oxidative status and histology of pancreas in alloxan- induced diabetic rats. Folia Morphol (Warsz) 2019; 79(1): 113-119.

20. Ashafa AOT, Balogun FO, Adegbegi AJ. Inhibitory potentials and kinetics on the inhibition of carbohydrate hydrolysing enzymes by the pod and seed extracts of Lessertia montana (fabaceae) E. Philip \& R.A Dyer. J. Appl. Pharm. Sci 2019; 9(01): 042-050.

21. Do QD, Angkawijaya AE, Tran-Nguyen $P L$, Huynh $L H$, Soetaredjo FE, Ismadji S, Ju YH. Effect of extraction solvent on total phenol content, total flavonoid content, and antioxidant activity of Limnophila aromatica. J. Food Drug Annal, 2014; 22(3): 296-302.

22. Sepahpour S, Selamat J, Manap MYA, Khatib A, Razis AFA. Comparative analysis of chemical composition, antioxidant activity and quantitative characterization of some phenolic compounds in selected herbs and spices in different solvent extraction systems. Molecules 2018; 23: 402.

23. Morakinyo AO, Akindele AJ, Ahmed J. Modulation of antioxidant enzymes and inflammatory cytokines: Possible mechanism of anti-diabetic effect of ginger extracts. Afr. J. Biomed. Res 2011; 14: 195-202.

24. Onyesife CO, Ogugua VN, Anaduaka EG. Hypoglycemic potentials of ethanol leaves extract of black pepper (Piper nigrum) on alloxan-induced diabetic rats. Ann Biol Res 2014; 5(6):26-31.

25. Shakya VK, Saxena RC, Shakya A. Effect of ethanolic extract of Allium sativum bulbs on streptozotocininduced diabetic rats. J. Chem. Pharm. Res 2010; 2(6): 171-175. 